\title{
STUDI KASUS KETERLAMBATAN PROYEK KONSTRUKSI \\ DI PROVINSI JAWA TIMUR BERDASARKAN KONTRAK KERJA
}

\author{
Fredy Kurniawan ${ }^{1}$, Diah Ayu Restuti Wulandari ${ }^{2}$, dan Lilian Arlista Ayu ${ }^{3}$ \\ ${ }^{2}$ Prodi Teknik Sipil, Universitas Narotama,Fredy@narotama.ac.id \\ ${ }^{3}$ Prodi Teknik Sipil, Universitas Narotama,Diah.wulandari@narotama.ac.id \\ IProdi Teknik Sipil, Universitas Narotama, Lielyanayu@gmail.com
}

\begin{abstract}
ABSTRAK
Perkembangan pembangunan infrastruktur yang semakin meningkat melahirkan pesatnya perkembangan perusahaan jasa yang bergerak dibidang konstruksi. Keterlambatan merupakan salah satu kendala bagi pembangunan karena waktu penyelesaian tidak sesuai dengan yang telah ditetapkan pada dokumen kontrak pekerjaan.

Keterlambatan proyek konstruksi berarti bertambahnya waktu pelaksanaan penyelesaian proyek yang telah direncanakan dan tercantum dalam dokumen kontrak yang telah disetujui kedua belah pihak yaitu pihak pertama dan kedua. Penelitian ini adalah untuk mencari faktor-faktor yang mempengaruhi keterlambatan proyek konstruksi, mengidentifikasi peran perundang-undangan, dan mengidentifikasi kontrak kerja.

Metode penelitian ini adalah kualitatif yaitu dengan observasi dan wawancara bersama narasumber dari Dinas Pekerjaan Umum Dan Tata Ruang yaitu PPK dan staff. Juga narasumber dari kontraktor swasta yaitu supervisor, estimator struktur, dan beberapa staff.

Pada lingkup proyek Pemerintah, 3 faktor dominan yang mempengaruhi keterlambatan proyek konstruksi adalah cuaca, tenaga kerja, dan desain. Pada lingkup proyek Swasta, 3 faktor dominan yang mempengaruhi keterlambatan proyek konstruksi adalah cuaca, material, dan keuangan. Undang-undang yang mengatur keterlambatan adalah UU No.2/2017 pasal 54 ayat (1) dan (2), Perpres No.54/2010 Jo Perpres No.35/2011 Jo Perpres No.70/2012 dan LKPP No.14/2012. Klausul tentang keterlambatan dalam kontrak kerja Pemerintah adalah terdapat pada SSUK yaitu kontrak kritis, SSKK yaitu termin, dan garansi bank. Klausul pada kontrak kerja Swasta yaitu pasal wanprestasi beserta sanksinya, dan garansi bank.
\end{abstract}

Kata kunci: Proyek konstruksi, keterlambatan, faktor-faktor, perundang-undangan, kontrak kerja.

\begin{abstract}
The development of increasing infrastructure development gave birth to the rapid development of service companies engaged in construction. Delay is one of the obstacles to development because the completion time does not match the one specified in the employment contract document.

The delay in the construction project means the increase in the timing of the completion of the planned project and is contained in the contract documents agreed by both parties, namely the first and second parties. This study is to look for factors that affect the delays of construction projects, identify the role of legislation, and identify contracts.

This research method is qualitative that is by observation and interview with resource person from Dinas Pekerjaan Umum Dan Tata Ruang that is PPK and staff. Also speakers from private contractors are supervisors, structural estimators, and some staff.

On the scope of Government projects, the three dominant factors that affect the construction project's delays are weather, labor, and design. On the scope of Private projects, the three dominant factors that affect construction project delays are weather, material, and finance. The laws governing the delay are Law No.2 / 2017 article 54 paragraph (1) and (2), Perpres No.54 / 2010 Jo Perpres No.35 / 2011 Jo Perpres No.70 / 2012 and LKPP No.14 / 2012. The clause on the delay in the government work contract is in the SSUK, namely the critical contract, the term SSKK, and the bank's guarantee. Clauses on Private contracts namely the breach of wanprestasi and sanctions, and bank guarantees.
\end{abstract}

Keywords: Project construction, delays, factors, legislation, contracts. 


\section{PENDAHULUAN}

\section{Latar Belakang}

Keterlambatan proyek konstruksi berarti bertambahnya waktu pelaksanaan penyelesaian proyek yang telah direncanakan dan tercantum di dalam kontrak (Kusjadmikahadi, 1999). Keterlambatan pelaksanaan proyek umumnya selalu menimbulkan akibat yang merugikan bagi pemilik maupun kontraktor karena dampak keterlambatan adalah konflik dan perdebatan tentang apa dan siapa yang menjadi penyebab, juga tuntutan waktu, dan biaya tambah (Praboyo, 1999).

Berdasarkan studi kasus beberapa proyek konstruksi di Provinsi Jawa Timur sebagian besar mengalami kendala keterlambatan dalam penyelesaiannya yang disebabkan oleh beberapa faktor. Berbagai cara dapat dilakukan untuk mengantisipasi dan menjadi solusi akibat terjadinya keterlamabatan. Namun keterlambatan masih juga sering terjadi, maka dari itu dalam penelitian ini penulis ingin melakukan studi kasus mengenai faktor-faktor yang menyebabkan keterlambatan, peranan peraturan perundang-undangan dalam menyikapi keterlambatan proyek konstruksi dan penerapan penaggulangan keterlambatan proyek konstruksi di Jawa Timur ditinjau dari sisi kontrak atau sesuai dokumen kontrak.

\subsection{Rumusan Masalah}

1. Faktor-faktor apa saja yang mempengaruhi keterlambatan proyek konstruksi?

2. Bagaimana peran perundang-undangan dalam menyikapi keterlambatan proyek kontruksi?

3. Bagaimana penerapan penanggulangan keterlambatan proyek konstruksi ditinjau dari sisi kontrak?

\subsection{Batasan Masalah}

1. Studi kasus pada dokumen kontrak kontruksi proyek pembangunan gedung yang terletak di daerah Jawa Timur khususnya sekitar kawasan Jombang, Madiun dan Gresik pada Tahun 2015- Akhir Tahun 2017

2. Peran peraturan perundang-undangan dalam menyikapi masalah keterlambatan proyek kontruksi.

3. Peran hukum kontrak dalam mengantisipasi keterlambatan proyek konstruksi.

\subsection{Tujuan Penelitian}

1. Menganalisis Faktor-faktor yang mempengaruhi keterlambatan proyek konstruksi di Jawa Timur.

2. Mengantisipasi keterlambatan proyek kontruksi mengacu pada hukum kontrak dan peraturan perundang-undangan yang berlaku.

3. Mengidentifikasi penerapan penanggulangan keterlambatan proyek konstruksi di Jawa Timur ditinjau dari sisi kontrak.

\subsection{Manfaat Penelitian}

1. Untuk memperoleh pengetahuan dan wawasan mengenai peran hukum kontrak untuk mengantisipasi keterlambatan proyek konstruksi 
2. Penerapan peranan peraturan perundang-undangan yang berlaku dalam menyikapi keterlambatan proyek konstruksi.

3. Mengantisipasi keterlambatan proyek konstruksi dengan mengacu pada dokumen kontrak yang telah disepakati di awal.

\section{TINJAUAN PUSTAKA}

\section{Pengertian Proyek Konstruksi}

Menurut Soeharto (1995), Kegiatan proyek dapat diartikan sebagai satu kegiatan sementara yang berlangsung dalam jangka waktu terbatas dengan alokasi sumber daya tertentu dan dimaksudkan untuk melaksanakan tugas yang sasarannya telah di gariskan dengan jelas.

\section{Pengertian Manajemen Proyek}

Menurut Dipohusodo (1996), Manajemen proyek merupakan proses terpadu dimana individu-individu sebagai bagian dari organisasi diliatkan untuk memelihara, mengembangkan, mengendalikan, dan menjalankan program-program, yang semuanya diarahkan pada sasaran yang telah ditetapkan dan berlangsung menerus seiring dengan berjalannya waktu.

\section{Pengertian Kontrak Kerja}

Kontrak merupakan dokumen yang mempunyai kekuatan hukum yang memuat persetujuan bersama secara sukarela, dimana pihak pertama berjanji untuk memberikan jasa dan menyediakan material untuk membangun proyek bagi pihak kedua, sedangkan pihak kedua berjanji untuk membayar sejumlah uang sebagai imbalan untuk jasa dan material yang telah digunakan (Soeharto, 1997).

Kontrak dibagi atas beberapa jenis, diantaranya adalah sebagai berikut :

1. Kontrak berdasarkan Aspek Perhitungan Biaya.

a. Fixed Lump Sum Price Contract, Yaitu Kontrak Harga Pasti.

Kontrak ini diatur dalam PP No.29 Tahun 2000 pasal 21 ayat (1) tentang penyelengara jasa konstruksi

b. Unit Price Contract, Yaitu Kontrak Harga Satuan.

Kontrak ini diatur dalam PP No.29 Tahun 2000 pasal 21 ayat (2) tentang penyelenggara jasa konstruksi.

2. Kontrak bedasarkan Aspek perhitungan jasa.

a. Cost Without Fee, Yaitu kontrak dengan perhitungan Biaya Tanpa Jasa.

b. Cost Plus Fee, Yaitu kontrak dengan perhitungan Biaya Ditambah Jasa.

c. Cost Plus Fixed Fee, Yaitu kontrak dengan perhitungan Biaya Ditambah Jasa Pasti.

3. Kontrak berdasarakan Aspek Cara pembayaran.

a. Monthly Payment, Yaitu kontrak dengan cara pembayaran bulanan.

b. Stage Payment, Yaitu kontrak dengan cara pembayaran atas prestasi.

c. Contractor full prefinance, Yaitu kontrak dengan cara pembayaran pra pendanaan penuh dari penyedia jasa.

4. Kontrak berdasarkan Aspek Pembagian Tugas.

a. Bentuk Kontrak Konvensional.

b. Bentuk Kontrak Spesialis.

c. Bentuk Kontrak Rancang Bangun.

d. Bentuk Kontrak Swakelola. 

e. Bentuk Kontrak EPC.
f. Bentuk Kontrak BOT / PPP.
g. Metode Construction Management.

\section{Keterlambatan Proyek Konstruksi}

Menurut Kusjadmikahadi ( Dalam Leonda, 2008), Keterlambatan Proyek Konstruksi berarti bertambahnya waktu pelaksanaan penyelesaian proyek yang telah direncanakan dan tercantum dalam dokumen kontrak.

Faktor-faktor yang mempengaruhi keterlambatan proyek konstruksi

Menurut penelitian yang dilakukan oleh Wirabakti, et. al., (2014) Keterlambatan penyelesaian pekerjaan didasari beberapa faktor antara lain Tenaga kerja, bahan, karakteristik tempat, manajerial, peralatan, keuangan, fisik bangunan, desain, cuaca, kejadian tidak terduga dan kebijakan pemerintah.

\section{Peraturan Perundang-Undangan Jasa Konstruksi}

1. UU No. 2 Tahun 2017

2. Perpres No.54/2010 Jo Perpres No.35/ 2011 Jo Perpres No.70/2012

3. LKPP No. 14 Tahun 2012

\section{Klausula Kontrak Kerja}

Kebijakan pengadaan ( procurement policy) suatu perusahaan komersil ataupun badan pemerintah dalam hal ini khususnya pada bidang konstruksi dinyatakan dalam bentuk klausula-klausula kontrak standar (Tumembow., Tjakra., Arsjad, 2016). Dan diatur dalam Dokumen kontrak kerja.

\section{Dalam Kontrak Kerja Pemerintah :}

1. Keterlambatan Pelaksanaan Pekerjaan dan Kontrak Kritis (Syarat-Syarat Umum Kontrak / SSUK )

2. Pembayaran Prestasi Pekerjaan (Syarat-Syarat Khusus Kontrak / SSKK )

3. Surat Jaminan Pelaksanaan dari Bank (Garansi Bank)

\section{Dalam Kontrak Kerja Swasta}

1. Wanprestasi

2. Sanksi

3. Jaminan Pribadi dan Garansi Bank

\section{METODOLOGI PENELITIAN}

\section{Metode Penelitian}

Pada penelitian ini penulis menggunakan metode Naturalistic / Kualitatif. Dengan diagram alir penelitian sebagai berikut: 


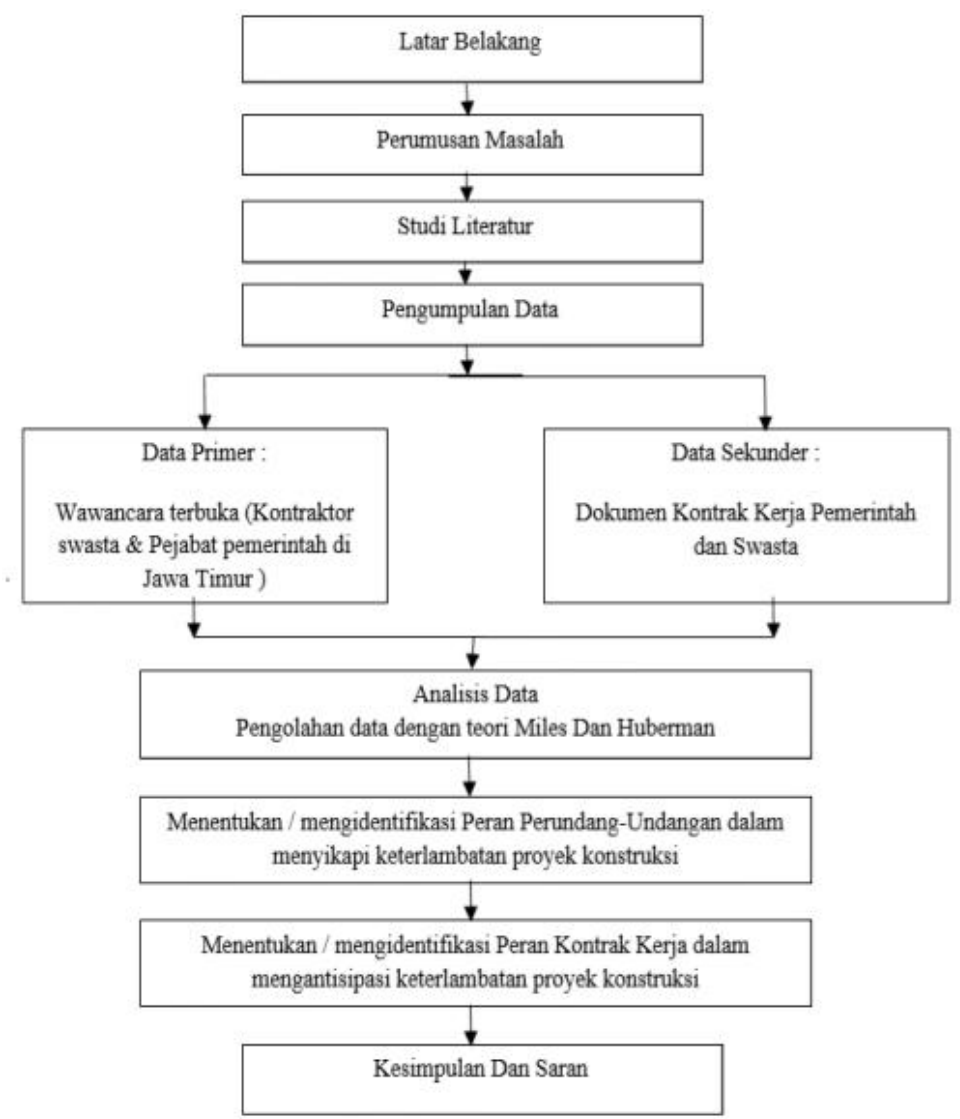

Gambar 1. Diagram Alir Penelitian

\section{ANALISIS DAN PEMBAHASAN}

\section{Observasi Dan Wawancara}

Pada penelitian ini peneliti melakukan observasi yang secara terang-terangan (overt observation). dan wawancara secara semiterstruktur (Semistructured Interview). Dengan subjek dari pejabat Pemerintah yaitu beberapa PPK dan staff dan dari kontraktor Swasta yaitu Supervisor, Estimator struktur dan beberapa staff.

\section{Analisis Data}

\section{Data Reduction}

Pada tahap Data Reduction / Reduksi data ini penulis merangkum dan memfokuskan faktor-faktor pokok supaya tidak rumit dan kompleks lagi dan lebih mudah untuk difahami. Data yang didapatkan berupa informasi mengenai faktor-faktor yang mempengaruhi keterlambatan proyek konstruksi di Jawa Timur.

\section{Data Display}

Setelah data di reduksi, maka data disajikan dalam bentuk data display untuk memudahkan dalam memahami pola yang merupakan faktor dominan yang mempengaruhi keterlambatan proyek konstruksi di Jawa Timur. 
Faktor pada proyek pemerintah

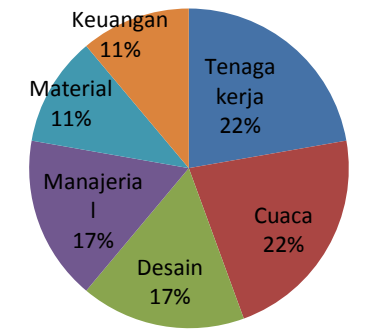

Gambar 2. Faktor Dominan Proyek Pemerintah

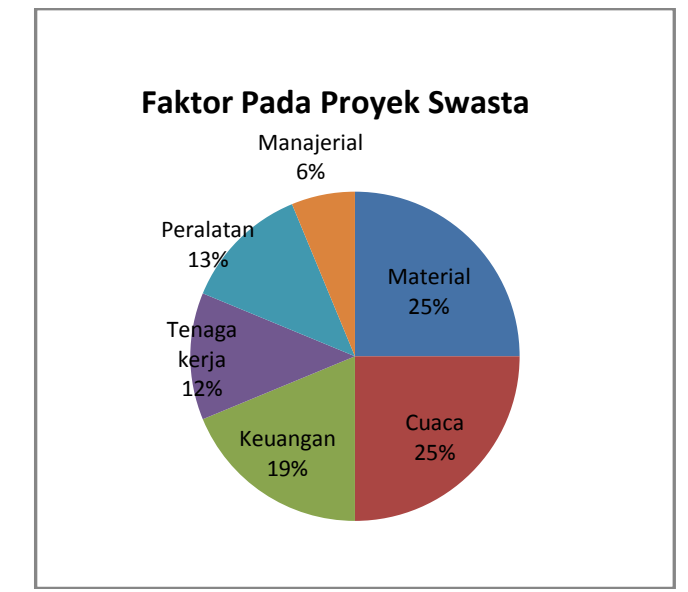

Gambar 3. Faktor Dominan Proyek Swasta

\section{Conclusion/Verification}

Berdasarkan pola yang di hasilkan dan dapat dilihat pada Data Display (penyajian data), maka dapat dilihat dengan jelas bahwa fakor dominan yang mempengaruhi keterlambatan proyek kontsruksi di daerah Provinsi Jawa Timur baik dalam lingkup Pemerintah maupun Swasta adalah di dominasi oleh faktor cuaca, yaitu tingginya intensitas curah hujan. Hal ini didukung dengan kondisi real yang terjadi di lapangan di setiap penghujung tahun sekitar bulan Agustus-Desember. Seperti halnya yang kita lihat dan alami dalam 5 bulan terakhir ini yaitu pada bulan Agustus-Desember 2017.

\section{Pembahasan}

Dari hasil analisis data yang telah dilakukan oleh penulis, maka dapat kita lihat suatu pola dari faktor-faktor yang mempengaruhi keterlambatan. Dari data display diatas dapat terlihat dengan jelas bahwa faktor cuaca kontras menjadi faktor dominan dikedua sektor yaitu Pemerintah dan Swasta.

Pada proyek Pemerintah, faktor lain yang mendominasi selain cuaca adalah faktor tenaga kerja / tenaga ahli (Sumber Daya Manusia). Hal ini tentu disebabkan karena kurangnya skill dari pekerja yang sesuai dengan standar pekerjaan yang dilakukan dan sesuai dengan profesi yang di emban. Misalnya ada beberapa pekerja yang tidak memiliki Sertifikat Keahlian atau ada beberapa pengawas yang berpendidikan tinggi tetapi dalam bidang lain seperti misalnya Hukum, hal ini jelas 
menyimpang karena di lapangan yang di butuhkan adalah keahlian teknis khusunya dibidang Teknik Sipil. Hal ini sesuai dengan pendapat Fansuri (2014), dalam jurnal yang berjudul "Penyebab Terjadinya Keterlambatan Waktu Penyelesaian Proyek Konstruksi Di Dinas PU. Bina Marga Kabupaten Sumenep” yang menyatakan bahwa Tenaga kerja merupakan salah satu faktor yang mempengaruhi keterlambatan proyek konstruksi. Faktor berpengaruh berikutnya adalah desain, yaitu perubahan pada desain. Hal ini dikarenakan pada proyek pemerintah desain suatu bangunan menyesuaikan dengan kebutuhan khalayak ramai karena sebagian besar bangunan khususnya gedung adalah dibangun untuk kepentingan umum / fasilitas umum dengan menyesuaikan manfaat dan juga kapasitas bangunan tersebut.

Demikian halnya dengan proyek Swasta, faktor cuaca juga mendominasi keterlambatan proyek konstruksi. Kemudian untuk faktor lainnya yang paling mendominasi adalah faktor material. Hal ini sesuai dengan pendapat Hasibuan, et. al., (2013), pada jurnal yang berjudul "Analisa Manajemen Terhadap Faktor Keterlambatan Proyek Konstruksi di Lingkungan Dinas Pariwisata Kabupaten Rokan Hulu" menyatakan bahwa Bahan / Material merupakan salah satu faktor yang mempengaruhi keterlambatan proyek konstruksi. Dan setelah penulis teliti lebih lanjut, faktor ini disebabkan karena spesifikasi material / bahan ditentukan oleh pemilik (owner), jadi material yang digunakan adalah sesuai dengan selera pemilik (owner). Oleh karena itu, material yang sesuai seringkali susah ditemukan di pasaran. Selain itu kadang pemikiran pemilik (owner) juga berubah seiring berjalannya waktu pelaksanaan proyek, yaitu mengenai penggantian material karena ternyata pemilik (owner) menemukan material yang lebih bagus, lebih murah, atau lebih sesuai selera.

\section{Identifikasi Peran Peraturan Perundang-Undangan}

Penanganan keterlambatan yang disebabkan oleh berbagai faktor diatas telah diatur dalam Peraturan Perundang-Undangan. Diantaranya yaitu Undang-Undang No.2 Tahun 2017 tentang Jasa Konstruksi, yaitu pada pasal 54 ayat (1) dan (2) yang mewajibkan penyedia jasa menyerahkan hasil pekerjaan secara tepat biaya, waktu dan mutu atau jika tidak maka penyedia jasa dikenai ganti rugi sesuai dalam kontrak.

Kemudian pada Perpres No. 54 Tahun 2010 Jo Perpres No.35 Tahun 2011 Jo Perpres No. 70 Tahun 2012 pasal (120) mengatakan bahwa "Penyedia barang / jasa yang terlambat menyelesaikan pekerjaan dalam jangka waktu sebagaimana ditetapkan dalam kontrak karena kesalahan penyedia barang / jasa, dikenakan denda keterlambatan sebesar 1/1000 (satu perseribu) dari nilai kontrak atau nilai bagian kontrak untuk setiap hari keterlambatan". Pada Perpres No.54 Tahun 2010 disebutkan tidak melampaui besarnya jaminan pelaksanaan, sedangkan pada Perpres No.70 Tahun 2012 maksimal denda tidak disebutkan. Dan denda maksimal 5\% pada Perpres No.54 Tahun 2010 tidak diatur lagi.

Peraturan selanjutnya adalah dalam LKPP (Peraturan Lembaga Kebijakan Pengadaan Barang / Jasa Pemerintah) No. 14/2012 yang mengatur tentang keterlambatan proyek konstruksi menyebutkan besarnya denda kepada penyedia barang / jasa yaitu: "1/1000 (satu perseribu) dari harga bagian kontrak yang tercantum dalam kontrak dan belum dikerjakan, apabila bagian pekerajaan dimaksud sudah dilaksanakan dan dapat berfungsi; atau 1/1000 (satu perseribu) dari harga kontrak, apabila bagian barang yang sudah dilaksanakan belum berfungsi”. 


\section{Identifikasi Peran Kontrak Kerja}

Penanganan keterlambatan yang disebabkan oleh berbagai faktor diatas telah diatur juga dalam kontrak kerja sesuai standar masing-masing. Pada proyek pemerintah diatur dalam Lampiran Peraturan Menteri Pekerjaan Umum No :07/PRT/M/2014 Tentang perubahan kedua atas Peraturan Menteri Pekerjaan Umum Nomor 07/PRT/M/2011 Tentang standar dan pedoman pengadaan pekerjaan konstruksi dan jasa konsultasi Buku PK 01 HS: Pascakualifikasi pelelenagan umum / pemilihan langsung), Kontrak Harga Satuan, yaitu pada SSUK (Syarat-Syarat Umum Kontrak) bagian B.6 Penghentian dan Pemutusan Kontrak No.43 Keterlambatan Pelaksanaan Pekerjaan dan Kontrak Kritis menyatakan "Apabila penyedia terlambat melaksanakan pekerjaan sesuai jadwal, maka PPK harus memberikan peringatan secara tertulis atau dikenakan ketentuan tentang kontrak kritis". Kontrak dinyatakan kritis apabila :'Dalam periode I (rencana fisik pelaksanaan 0\% - 70\% dari kontrak), realisasi fisik pelaksanaan terlambat lebih besar 10\% dari rencana; Dalam periode II (rencana fisik pelaksanaan 70\% -100\% dari kontrak), realisasi fisik pelaksanaan terlambat lebih besar 5\% dari rencana; Rencana fisik pelaksanaan 70\% - 100\% dari kontrak, realisasi fisik pelaksanaan terlambat kurang dari 5\% dari rencana dan akan melampaui tahun anggaran berjalan".

Penanganan Kontrak kritis ini dilakukan dengan pemutusan kontrak oleh PPK karena pekerjaan dinyatakan selesai atau terjadi keadaan kahar, Maka PPK membayar pada penyedia jasa sesuai prestasi melalui rapat pembuktian / SCM (Show Cause Meeting), Sedangkan keterlambatan yang melampaui tahun anggaran diberi kesempatan 50 (lima puluh) hari sejak berakhir pelaksanaan pekerjaan dan dengan denda 1/1000 dari nilai kontrak / bagian kontrak atau dengan Adendum (Untuk menentukan anggaran pada tahun berikutnya).

Dalam SSKK (Syarat-Syarat Khusus Kontrak) pada Permen PU mengatur tentang pembayaran atas prestasi pekerjaan yaitu berupa termin I realisasi fisik $30 \%$, Termin II realisasi fisik 55\%, Termin 3 realisasi fisik 80\%, Termin IV realisasi fisik $100 \%$. Masing-masing termin adalah pembayaran 25\%. Penentuan Termin ini tidak selalu sama seperti yang telah disebutkan di atas tetapi penentuan besar persentase realisasi fisik serta pembayarannya sesuai kebijakan PPK Dinas setempat.

Pada kontrak kerja Swasta, klausula yang mengatur tentang keterlambatan adalah pasal "Wanpretasi" menyatakan bahwa Pihak Kedua dinyatakan wanpretasi atau ingkar janji, yakni apabila "Pihak Kedua tidak memenuhi kewajiban melaksanakan pekerjaan berdasarkan perjanjian sama sekali, Pihak Kedua tidak memenuhi kewajiban berdasarakan perjanjian ini secara tepat waktu, Pihak Kedua memenuhi kewajiban pekerjaan dan tepat waktu, tetapi hasil pekerjaan tidak sesuai dengan surat penawaran beserta lampirannya, Pihak Kedua melakukan suatu tindakan yang menurut perjanjian ini tidak boleh dilakukan dan / atau pernyatanan dan jaminan yang diberikan pihak Kedua kepada pihak Pertama terbukti tidak benar". Dengan "Sanksi" pihak Kedua wajib melakukan pembayaran denda keterlambatan kepada pihak Pertama sebesar 1/1000 dari Nilai pekerjaan untuk setiap hari keterlambatan, dan tidak boleh melebihi 14 (empat belas) hari terhitung sejak hari pertama keterlambatan pekerjaan tersebut terjadi. Semua ini dibuktikan melalui surat pemberitahuan peringatan atau teguran dari pihak Pertama kepada Pihak Kedua. 


\section{KESIMPULAN DAN SARAN}

\section{Kesimpulan}

Pada lingkup proyek Pemerintah, 3 faktor dominan yang mempengaruhi keterlambatan proyek konstruksi adalah cuaca, tenaga kerja, dan desain. Pada lingkup proyek Swasta, 3 faktor dominan yang mempengaruhi keterlambatan proyek konstruksi adalah cuaca, material, dan keuangan.

Peraturan perundang-undangan yang mengatur tentang keterlambatan proyek konstruksi sudah diatur dalam Undang-undang No.2 Tahun 2017 yaitu membahas tentang penyedia jasa harus menyerahkan pekerjaan secara tepat biaya, waktu, dan mutu, atau dikenai ganti rugi sesuai dalam kontrak. Dalam Perpres No.54 Tahun 2010 Jo perpres No.35 Tahun 2011 Jo perpres no. 70 Tahun 2012 yang membahas tentang jika penyedia jasa terlambat menyelesaikan pekerjaan maka dikenakan denda sebesar 1/1000 dari nilai kontrak / bagian kontrak untuk setiap hari keterlambatan. Kemudian Dalam LKPP (Peraturan Lembaga Kebijakan Pengadaan Barang / Jasa Pemerintah) No. 14/2012 juga membahas tentang denda keterlambatan yaitu 1/1000 dari nilai kontrak atau bagian kontrak.

Kontrak Kerja Pemerintah maupun Swasta sudah mengatur mengenai keterlambatan penyelesain pekerjaan proyek Konstruksi. Pada kontrak kerja Pemerintah terdapat SSUK (Syarat-Syarat Umum Kontrak) yang membahas tentang keterlambatan hingga jika terjadi kontrak kritis dan beserta penanganan kontrak kritis tersebut. Penanganan kontrak ktitis ini melalui rapat pembuktian /SCM (Show Cause Meeting) Tahap I,II, dan III. Kemudain SSKK (Syarat-Syarat Khusus Kontrak) yang membahas tentang termin pembayaran yaitu termin I, II, III, dan IV. Masing- masing termin adalah pembayaran sebesar 25\%. Besar Persentase termin realisasi fisik ditentukan oleh PPK Dinas Setempat. Selain SSUK dan SSKK juga terdapat Garansi Bank sebagai surat jaminan.

Pada kontrak kerja Swasta, terdapat pasal yang mengatur tentang keterlambatan yaitu pasal "Wanprestasi" yang membahas tentang jika penyedia jasa ingkar janji maka dikenai sanksi berupa denda 1/1000 dari nilai pekerjaan setiap hari. Dengan alternatif diberi kesempatan 14 hari dengan membayar denda sebesar 5\% dari pembayaran yang telah di terima dari pihak pertama. Kemudian dalam kontrak swasta ini juga terdapat jaminan pelaksanaan yang berupa garansi bank dan jaminan pribadi.

\section{Saran}

1. Penelitian ini dilakukan dengan sudut pandang yang global / umum dan menyeluruh. Jadi, lebih baik pada penelitian berikutnya ditentukan sudut pandang dengan detail yaitu sebagai kontraktor atau pemilik (owner).

2. Dari materi / referensi Peraturan perundang-undangan hendaknya di cantumkan undang-undang yang mengatur tentang Force Majeur. 


\section{DAFTAR PUSTAKA}

1. Andi, et. al., (2003). Faktor-Faktor Potensional Yang Dapat Mempengaruhi Waktu Pelaksanaan Konstruksi Yang Terdiri Dari Tujuh (7) Kategori. Universitas Kristen Petra. Surabaya.

2. Deshariyanto D, dan F. Subaidillah, (2013). Faktor-Faktor Yang Mempengaruhi Waktu Pelaksanaan Proyek Konstruksi di Dinas PU Bina Marga Kabupaten Sumenep, Jurnal Fakultas Teknik Universitas Wiraja Sumenep. Madura.

3. Kontrak Kerja, (2015). Kontrak Kerja Poyek Konstruksi Gedung. Dinas Pekerjaan Umum Dan Tata Ruang. Jawa Timur.

4. Dipohusodo, I., (1995). Manajemen Proyek dan Konstruksi Jilid I. Jakarta.

5. Dipohusodo, I., (1996). Manajemen Proyek dan Konstruksi Jilid 1. Kanisius. Yogyakarta.

6. Dipohusodo, I., (1996). Manajemen Proyek dan Konstruksi Jilid 2. Kanisius. Yogyakarta.

7. Esterberg, G. Kristin., (2002). Qualitative Methods In Social Research. Mc Graw hill. New York.

8. Fansuri, S., (2014). Penyebab Terjadinya Keterlambatan Waktu Penyelesaian Proyek Konstruksi Di Dinas PU Bina Marga Kabupaten Sumenep, Jurnal Teknik Sipil. Madura.

9. Faisal, Sanafiah., (1990). Penelitian Kualitatif : Dasar-dasar Aplikasi Yayasan Asih Asah Asuh Malang (YA3 Malang) edisi 1.

10. Hasibuan, et. al., (2013). Analisa Manajemen Terhadap Faktor Keterlambatan Proyek Konstruksi Di Lingkungan Dinas Pariwisata Kabupaten Rokan Hulu. Universitas Pasir Pangairan.

11. Ismael, I., (2013). Keterlambatan Proyek Konstruksi Gedung Faktor Penyebabnya Dan Tindakan Pencegahannya. Jurnal Momentum. Padang.

12. Ismaiel Dan Junaidi, (2014). Identifikasi Faktor-Faktor Yang Memepengaruhi Keterlambatan Pelaksanaan Pekerjaan Pada Proyek Pembangunan Gedung Di Kota Bukittinggi. Jurnal Momentum. Padang.

13. Kamaruzzaman, F., (2012). Studi Keterlambatan Penyelesaian Proyek Konstruksi (Study Of Delay In The Completion Of Construction). Jurnal Teknik Sipil Vo.12 No.2

14. Kurniawan, F., (2006). Penggunaan Penyelesaian Sengketa Pada Proyek Konstruksi. Jurnal Teknik Sipil. Surabaya

15. Kusjadmikahadi, R.A., (1999). Studi Keterlambatan Kontraktor Dalam melaksanakan Proyek konstruksi di Daerah Istimewa Yogyakarta. Universitas Gadjah Mada. Yogyakarta

16. Leonda, (2008). Studi Keterlambatan Penyelesaian Proyek Konstruksi Pada Tahun 2007 Di Daerah Belitung. Universitas Islam Indonesia. Yogyakarta

17. Lampiran Peraturan Menteri Pekerjaan Umum No: 07/PRT/M/2014 Tentang Perubahan Kedua Atas Peraturan Menteri Pekerjaan Umum No.07/PRT/M/2011 Tentang Standar dan Pedoman Pengadaan Pekerjaan Konstruksi Dan Jasa Konsultasi. Buku PK 01 HS: Kontrak Harga Satuan

18. Messah, et. al., (2013). Kajian Penyebab Keterlambatan Pelaksanaan Proyek Konstrruksi Gedung di Kota Kupang. Jurnal Teknik Sipil Universitas Nusa Cendana. Kupang. 
19. Miles, M.B \& Huberman A.M. (1984). Analisis Data Kualitatif, Terjemahan oleh Tjetjep Rohendi Rohidi. 1992. Universitas Indonesia. Jakarta

20. Perpres No.54 Tahun 2010 Jo Perpres No.35 Tahun 2011 Jo Perpres No.72 Tahun 2012 tentang Jasa Konstruksi.

21. Peraturan Lembaga Kebijakan Pengadaan Barang / Jasa Pemerintah No.14 Tahun 2012.

22. Proboyo, B., (1999). Keterlambatan Waktu Pelaksanaan Proyek : Klasifikasi dan Peringkat dari Penyebab-penyebabnya. Dimensi Teknik Sipil, Vol.1 no.2, September, pp. 49-58.

23. Setiawan, M.I., (2005). Faktor-Faktor Penentu dalam Pemilihan Jenis Kontrak Untuk Proyek Pembangunan Gedung Pertokoan.

24. Setiawan, M.I.,(2009). Rescheduling Waktu Pekerjaan Guna Optimasi Biaya Pembangunan Rusunawa Siwalankerto Surabaya.

25. Soeharto, I., (1995). Manajemen Proyek Dari Konseptual Sampai Operasional,Erlangga . Jakarta.

26. Soeharto, I., (1997). Manajemen Proyek Dari Konseptual Sampai Operasional,Erlangga . Jakarta.

27. Sudarsono, T.M et. al., (2014). Analisis Frekuensi Dampak, Dan Jenis Keterlambatan Pada Proyek Konstruksi. Universitas Kristen Petra. Surabaya.

28. Sugiyono, (2014). Metode Penelitian Kuantitatif, Kualitatif, dan R\&D. Bandung. Alfabeta.

29. Tistogondo, J (2004). Studi Efektifitas Waktu dan Biaya Pelaksanaan Erection PCI Girder dengan Metode Crawler Crane dan Roller Skate.

30. Undang-Undang No.2 Tahun 2017 tentang Jasa Konstruksi. Lembaran Negara RI No. 11Tahun 2017.

31. Wirabakti, et. al., (2014). Studi Faktor-Faktor Keterlambatan Proyek Konstruksi Bangunan Gedung. Jurnal Konstruksi Vol.6 No.1. 